\title{
SYNOPSIS OF THE TIPULID GENUS BITTACOMORPHA
}

BY CHARLES W. JOHNSON.

This interesting genus is very widely represented by the more common and conspicuous species $B$. clavipes Fabr., which extends throughout Eastern North America from the Atlantic to the Rocky Mountains. All the records from the Pacific Slope undoubtedly refer to B. occidentalis Aldrich (Psyche VII, p. 20I, 1895) and Osten Sacken (Psyche VII, p. 230, 1895). The B. sackenii described by von Röder from Nevada (Wiener Entom. Zeit., Heft 8, p. 230,189o) has also been recorded from Seattle, Washington, by Aldrich and re-described by him in Psyche VII, p. 2oo. A specimen from the mountains of North Carolina adds another species to our fauna.

\section{TABLE OF SPECIES}

I. Tibiæ annulated with snow white near the base.

Tibiæ not annulated, all the metatarsi white at the tip instead of the base. sackenii Röder.

2. Metatarsi more or less swollen.

Metatarsi not swollen in the slightest deyree, nor annulated at the base, and only those of the anterior tipped with white.

jonesi $\mathrm{n}$. sp.

3. Dorsum of thorax deep velvety black with a white median line. clavipes Fabr.

Dorsum of thorax shining black, the white median line wanting. occidentalis Aldr.

Bittacomorpha jonesi n. sp.

o Head blackish, front and face covered with a silvery white pollinose; antennæ about $4 \mathrm{~mm}$. in length, the two basal joints brown, the remainder black and strongly pubescent; palpi and proboscis yellowish. Dorsum of the thorax shining black, the remainder of the thorax including the scutellum dull yellow, slightly darker on the pleuræ; humeri, a lateral stripe extending to the base of the wing and pleuræ silvery white pollinose. Abdomen clavate, black, shining, posterior margins of the second, third and fourth segments, and the genitalia yellowish, the claspers black. Coxæ light yellow, base of the femora brown 
becoming gradually black toward the end; tibiæ black, annulated with white near the base; anterior metatarsi tipped with white, the others entirely black; the second and third joints of the tarsi white, the terminal joints black; halters dark brown. Wings grayish hyaline, the relative length of the second submarginal cell the same as in $B$. clavipes. Length of body $8 \mathrm{~mm}$., of wing $7 \mathrm{~mm}$., and of the posterior legs ${ }_{5} \mathrm{~mm}$.

One specimen from Mt. Taxoway, North Carolina, at an elevation of between 3000 and $5000 \mathrm{ft}$. Collected in August, 1904, by Mr. Frank M. Jones of Wilmington, Delaware, to whom I dedicate this interesting species.

Varying Abundance of Certain Butterflies. Many collectors of butterflies in New England have noticed the remarkable scarcity of Anosia plexppus during the last five or six summers, but little or no mention of this phenomenon has appeared in print. Since 1899 I have found it impossible to obtain supplies of larvæ for class-room use, where previously the species had swarmed. In Alstead, N. H., the almost total disappearance of the species was remarked even by non-entomological observers. In I899 it was common; in I 900 hardly a specimen could be found. Last year a diligent search revealed four of them in a region where they used to abound.

Current comment among members of the Cambridge Entomological Club suggests that Aglais milberti is rapidly increasing in abundance, particularly in eastern Massachusetts. My own observations seem to support this idea.

Laertias philenor appears occasionally in great numbers in the neighborhood of Boston, but after a season or two of plentifulness it vanishes. Along the southern border of New England, Papilio thoas and Callidryas eubule come and go. 'The range of each species widens and shrinks and widens again in response to certain changing conditions, but our knowledge of those conditions is very fragmentary. It would be interesting to compare a large series of observations, and perhaps such a comparison would help us to a better understanding of the struggle for existence among the butterflies.-W. L. W. Field. 

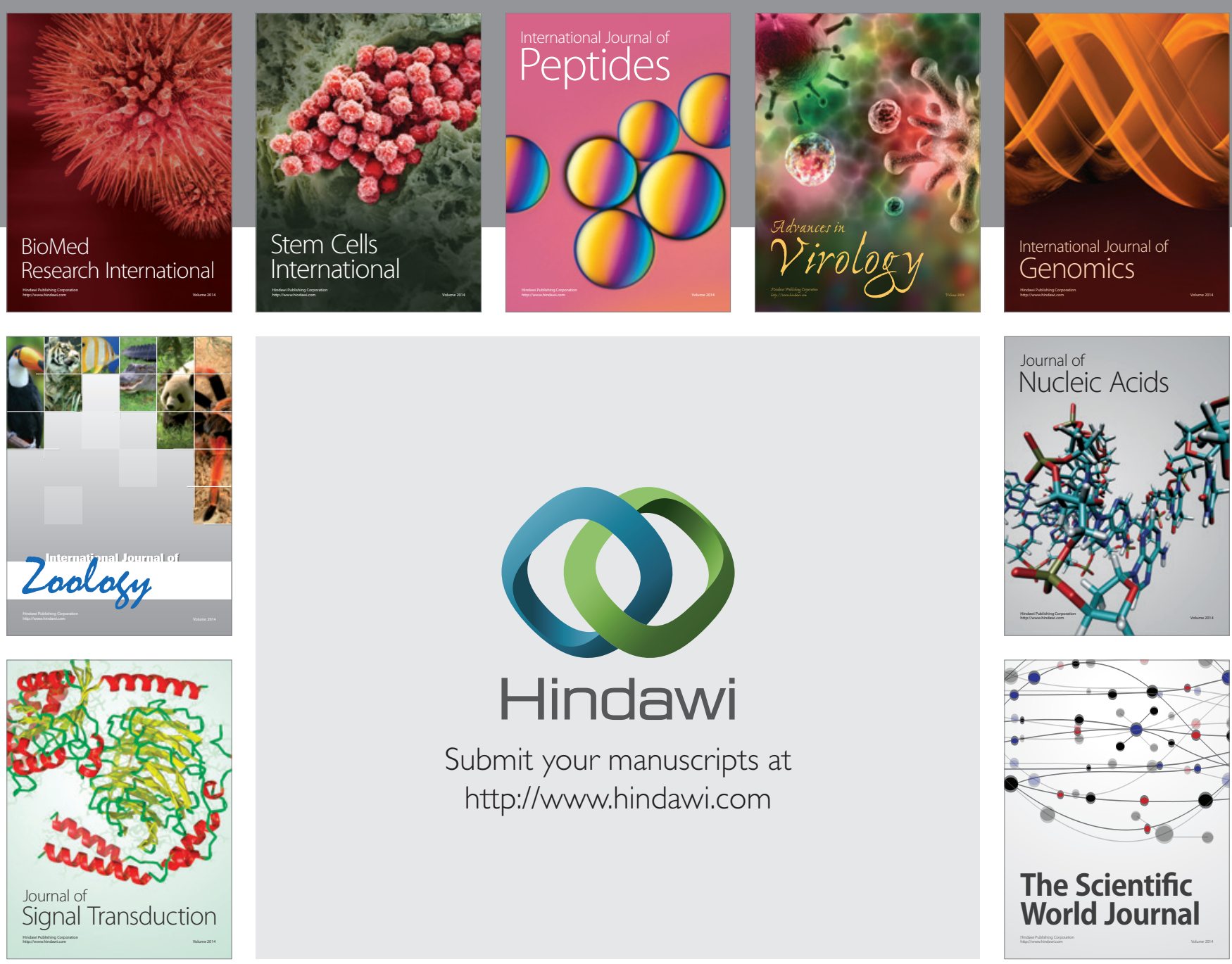

Submit your manuscripts at

http://www.hindawi.com
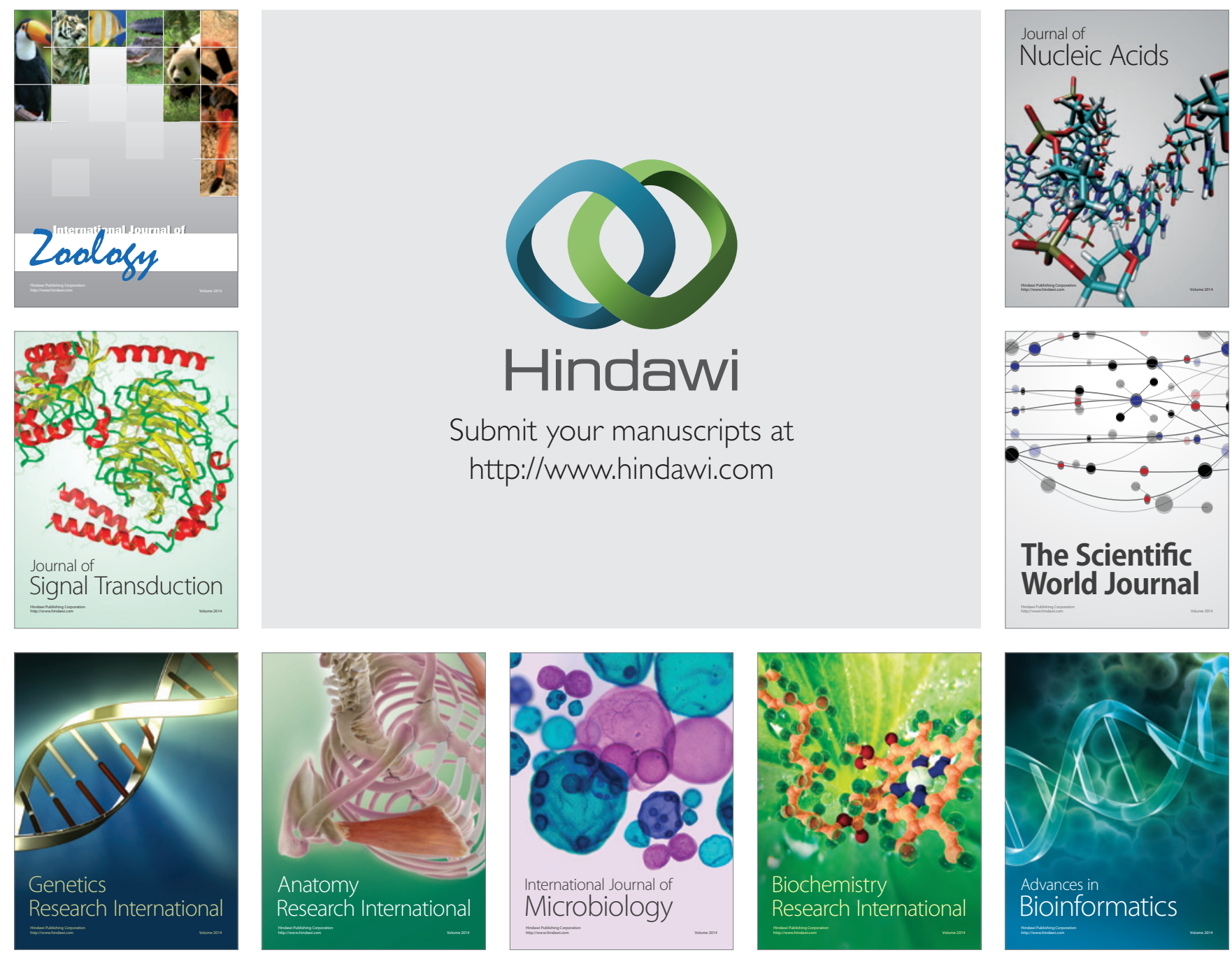

The Scientific World Journal
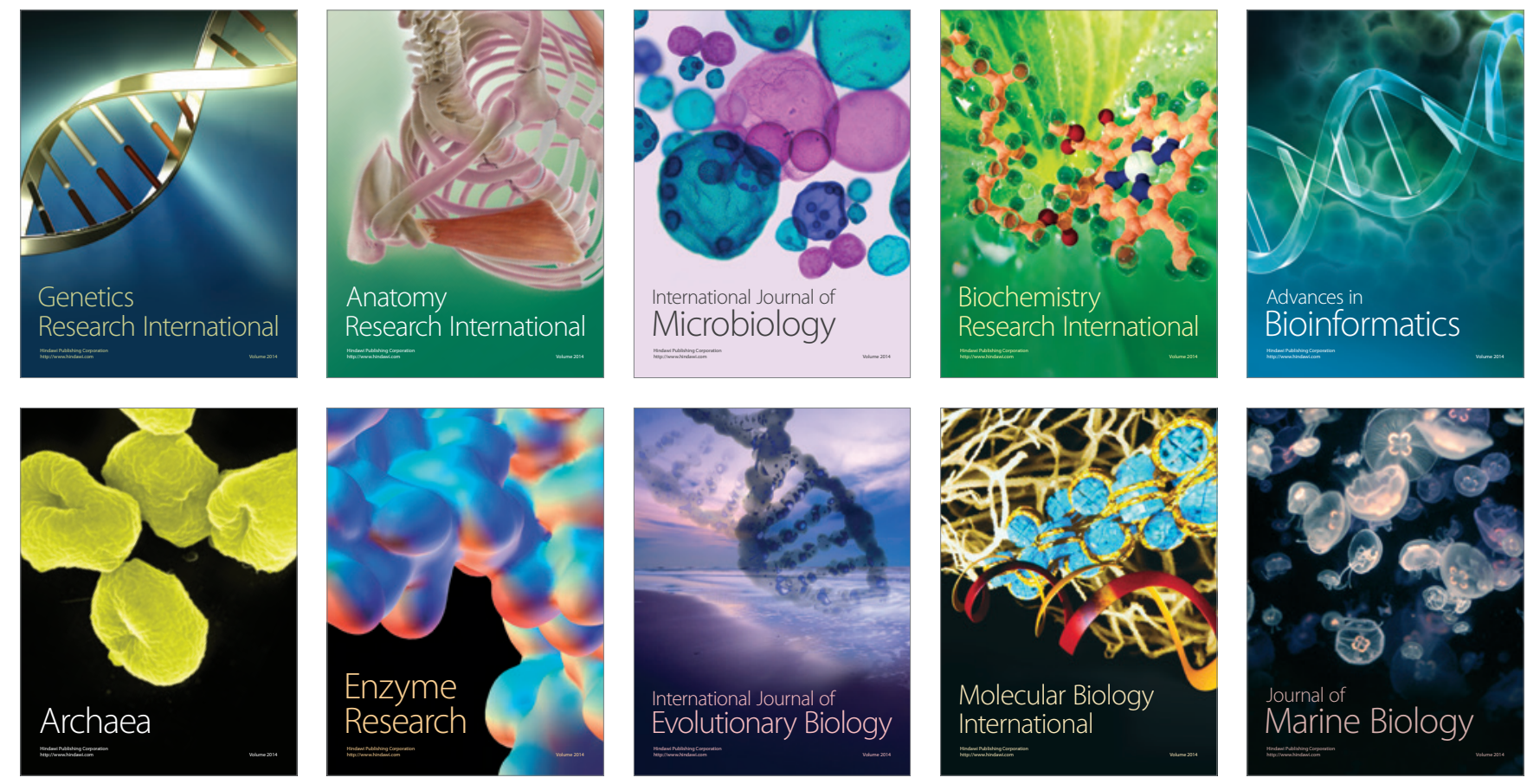